\title{
The Australia antigen in Brazilian healthy persons and in leprosy and leukaemia patients
}

F. M. SALZANO AND B. S. BLUMBERG

From the Departament de Genêtic, Institut de Ciências Naturais, Universidade Federal do Rio Grande $\vec{\circ}$ do Sul, Pôrto Alegre, Brazil, and the Institute for Cancer Research, Fox Chase, Philadelphia, Pennsylvania, USA

SYNOPSIS The distribution of the Australia antigen was investigated in 633 white and negroid healthy persons, 218 white and negroid leprosy patients, and 50 white leukaemia patients. The subjects were living at the time of the investigation in two southern Brazilian cities. Two of the patients with leukaemia showed the antigen, as also did three out of 358 negro subjects, but no reactors were found among the healthy white subjects and leprosy patients.

Australia antigen, so called because it was first found in the serum of an Australian aborigine, is detected using antisera from patients who have received large numbers of transfusions. The studies on the antigen have been summarized recently (Blumberg, Sutnick, and London, 1968). Soon after its discovery, the association of the antigen with hepatitis virus was established (Blumberg, Gerstley, Hungerford, London, and Sutnick, 1967a). Although the antigen is rare in normal American populations, it is found fairly often in patients with acute viral hepatitis (both 'infectious' and 'post-transfusion'), but not in patients with a variety of other liver diseases. Also it is often found in sera from cases of chronic disease characterized by a prolonged and (usually) severely impaired immune mechanism (Blumberg et al, 1968; Sutnick, London, Gerstley, Received for publication 11 April 1969.
Cronlund, and Blumberg, 1968; London, Sutnick, 은 and Blumberg, 1969). In these patients the presence $\rightarrow$ of the antigen identifies chronic anicteric hepatitis. The sera from chronic diseases in $\bar{N}$ which the antigen is found include Down's syndrome (mongolism), leukaemia, and chronic $\stackrel{N}{\circ}$ renal disease in patients undergoing haemodialysis. The antigen has been isolated from blood, and $\widetilde{2}$ under the electron microscope is seen to be a co particle of $200 \AA$ diameter which has the appear- $\overparen{\varnothing}$ ance of a virus (Bayer, Blumberg, and Werner, $\stackrel{?}{-}$ 1968). In addition to these disease associations 7 the antigen is common in apparently normal people living in parts of the tropics and tens of $\stackrel{\odot}{\square}$ millions of people probably carry it. These $\stackrel{\square}{\square}$ apparently normal people do not have overt $\overline{0}$ evidence of hepatitis but appear to be carriers of the disease. Their identification is useful in the screening tests to eliminate carriers of hepatitis. 
In some of these tropical regions the antigen is more often found in patients with lepromatous leprosy (particularly young males) than in patients with tuberculoid leprosy or in non-leprosy controls from the same region (Blumberg, Melartin, Lechat, and Guinto, 1967b; Blumberg, Friedlaender, and Woodside, 1969a). Where Australia antigen is very rare in the general population, eg, Italy, the United States of America, the frequency of Australia antigen is not increased in lepromatous leprosy patients who have been tested. An interesting feature of the distribution of the disease in tropical populations is that the family segregation is consistent with simple autosomal recessive inheritance (Blumberg, Melartin, Guinto, and Werner, 1966; Blumberg, Melartin, Guinto, and Lechat, 1969b).

\begin{tabular}{lcl}
\hline Sample & $\begin{array}{l}\text { No. } \\
\text { Studied }\end{array}$ & $\begin{array}{l}\text { No. with } \\
\text { Australia } \\
\text { Antigen }\end{array}$ \\
\hline $\begin{array}{l}\text { Healthy individuals } \\
\text { Whitcs, Florianópolis }\end{array}$ & 109 & 0 \\
$\begin{array}{l}\text { Whites, Pôrto Alegre } \\
\text { Whites, relatives of leukaemia patients }\end{array}$ & 120 & 0 \\
$\quad \begin{array}{l}\text { mainly from Pôrto Alegre } \\
\text { Light Mulattoes, Pôrto Alegre }\end{array}$ & 46 & 0 \\
$\begin{array}{l}\text { Dark Mulattoes, Pôrto Alegre } \\
\text { Negroes, Pôrto Alegre }\end{array}$ & 120 & 0 \\
Total & 118 & $2(0 \cdot 8 \%)$ \\
$\begin{array}{l}\text { Sick Persons } \\
\text { Leprosy Whites, Florianópolis }\end{array}$ & 633 & $3(0 \cdot 5 \%)$ \\
Leukaemic Whites, mainly from Port & 200 & 0 \\
$\quad$ Alegre & 18 & 0 \\
Total & 50 & $2(4.0 \%)$ \\
Grand total & 268 & $2(0 \cdot 7 \%)$ \\
\hline
\end{tabular}

Table I The distribution of Australia antigen in selected samples of southern Brazilian populations

$\begin{array}{ll}\text { Sample } & \text { Sex } \\ \text { F } & \frac{\text { Age Group }(y r)}{0-29} 30-59 \text { Over Unknown } \\ 60\end{array}$

Healthy individuals

White, Florianópolis

White, Pôrto Alegre

White, relatives of leukaemia patients mainly from Pôrto Alegre

Light Mulattoes, Pôrto Alegre

Dark Mulattoes, Pôrto Alegre

Negroes, Porto Alegre

Total

Sick persons

Leprosy, White, Florianópolis

Leprosy, Negroid, Florianópolis

Leukaemic Whites, mainly from Pôrto Alegre

Total

Grand total

\begin{tabular}{rrrrrr}
$33 \cdot 9$ & $66 \cdot 1$ & $63 \cdot 3$ & $34 \cdot 9$ & $1 \cdot 8$ & - \\
$44 \cdot 2$ & $55 \cdot 8$ & $47 \cdot 5$ & $43 \cdot 3$ & $9 \cdot 2$ & - \\
$47 \cdot 8$ & $52 \cdot 2$ & $41 \cdot 2$ & $58 \cdot 8$ & - & - \\
$25 \cdot 8$ & $74 \cdot 2$ & $55 \cdot 1$ & $42 \cdot 8$ & $2 \cdot 5$ & - \\
$30 \cdot 4$ & $69 \cdot 2$ & $51 \cdot 7$ & $43 \cdot 3$ & $5 \cdot 0$ & - \\
$36 \cdot 4$ & $63 \cdot 6$ & $44 \cdot 9$ & $49 \cdot 2$ & $5 \cdot 9$ & - \\
$35 \cdot 2$ & $64 \cdot 8$ & $51 \cdot 5$ & $43 \cdot 9$ & $4 \cdot 6$ & - \\
& & & & & \\
$51 \cdot 5$ & $48 \cdot 5$ & $23 \cdot 5$ & $62 \cdot 5$ & $12 \cdot 0$ & $2 \cdot 0$ \\
$66 \cdot 7$ & $33 \cdot 3$ & $5 \cdot 6$ & $61 \cdot 1$ & $22 \cdot 2$ & $11 \cdot 1$ \\
$52 \cdot 0$ & $48 \cdot 0$ & $50 \cdot 0$ & $40 \cdot 0$ & $10 \cdot 0$ & - \\
$52 \cdot 6$ & 47.4 & $27 \cdot 3$ & $58 \cdot 2$ & $12 \cdot 3$ & $2 \cdot 2$ \\
40.4 & 59.6 & $44 \cdot 3$ & $48 \cdot 1$ & 6.9 & 0.7 \\
\hline
\end{tabular}

Table II Sex, age, and genetic group of individuals studied

\section{Materials and Methods}

Blood was collected from (1) healthy white and negro subjects between December 1961 and Jum 1965 for gene flow studies and other inves gations (Salzano, Suñé, and Fetlauto, 196 Salzano, Rocha, and Tondo, 1968); (2) health whites and leprosy patients between August 19 and March 1964 for the study of the relationsh between genetic polymorphisms and leprost (Schwantes, Salzano, Castro, and Tondo, 196\$; Salzano et al, 1967); (3) leukaemic patients arefil their relatives betwen June and November $196^{5}$ for the investigation of blood group changes in leukaemia (Ayres, Salzano, and Ludwig, 1966⿸尸

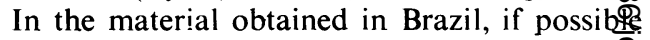
the red cells and plasma were immediateg separated after collection, the plasma being kedf in the deep freeze at about $-20^{\circ} \mathrm{C}$ until they were sent by air to Philadelphia for the determinatiofy of Australia antigen. Otherwise plasma wos frozen immediately and later with the other material sent to Philadelphia.

Australia antigen determinations were carried out in Philadelphia from June to August 1966, precipitation in agar gel using the doublediffusion micro-Ouchterlony technique describeg elsewhere (Blumberg and Riddell, 1963; Blumberg et al, 1966). The antiserum used was rabbit antiserum no. 6 (Melartin and Blumberg, 1966) ared a human antiserum. The material tested, there fore, was stored between four and a half years $\bar{\S}$ seven months. Since the Australia antigen wक present in sera or plasma stored for up to sq years (Blumberg, Alter, and Visnich, 1965), t $\overrightarrow{\text { Pe }}$ long storage of some of our material has probaby not affected the results.

\section{Results and Discussion}

Table I shows the distribution of Australia antigen in the samples tested and Tables II ard III furnish additional clinical information.

Fewer than half of the individuals studied we males and about half were distributed in the ag group 0 to 29 years. Some $80 \%$ of the leproøy patients had lepromatous leprosy which was generally of the mild type, and $20 \%$ of those wifi leukaemia showed the acute myeloblastic form The Australia antigen was present in only three of the 633 healthy persons studied $(0.5 \%)$, wets completely absent among the 218 leprosy patients tested, but was present in two of the 50 leukaemia patients. The individuals showigg Australia antigen were a dark Mulatto, a womaan, age 28; two Negroes, both male, were aged \$o and 67. All three came to the collecting post because they were receiving some kind of treatment but none presented abnormal haemsglobulins (Table II). The following is an account 


\begin{tabular}{|c|c|c|c|c|c|c|c|c|}
\hline \multirow[t]{2}{*}{ Genetic Group } & \multicolumn{4}{|c|}{ Type of Leprosy } & \multicolumn{4}{|c|}{ Severity of the Disease } \\
\hline & Lepromatous & Tuberculoid & Indeterminate & Unknown & Mild & Moderate & Severe & Unknown \\
\hline $\begin{array}{l}\text { Whites, Florianópolis } \\
\text { Negros, Florianópolis }\end{array}$ & $\begin{array}{l}79 \cdot 0 \\
88.9\end{array}$ & $\begin{array}{l}9 \cdot 5 \\
5 \cdot 5\end{array}$ & $\begin{array}{r}11.0 \\
5.6\end{array}$ & $\underline{0.5}$ & $\begin{array}{r}90 \cdot 5 \\
100 \cdot 0\end{array}$ & $\begin{array}{l}8 \cdot 5 \\
-\end{array}$ & $\frac{0.5}{-}$ & 0.5 \\
\hline Total & $79 \cdot 8$ & $9 \cdot 2$ & $10 \cdot 5$ & 0.5 & $91 \cdot 3$ & $7 \cdot 8$ & 0.5 & 0.4 \\
\hline
\end{tabular}

Table IIIa Clinical summary of the leprosy patients

\begin{tabular}{|c|c|c|c|c|}
\hline \multirow[t]{2}{*}{ Genetic Group } & \multicolumn{4}{|c|}{ Type of Leukaemia } \\
\hline & $\begin{array}{l}\text { Acute } \\
\text { Lympho- } \\
\text { blastic }\end{array}$ & $\begin{array}{l}\text { Acute } \\
\text { Myelo- } \\
\text { blastic }\end{array}$ & $\begin{array}{l}\text { Chronic } \\
\text { Lymphoid }\end{array}$ & $\begin{array}{l}\text { Chronic } \\
\text { Myeloid Other }\end{array}$ \\
\hline
\end{tabular}

Whites, mainly

from Pôrto

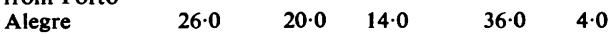

Table IIIb Clinical summary of leukaemic patients

of the main clinical findings observed in two patients who carried the antigen.

\section{ILLUSTRATIVE CASES}

Case 15704

A white woman, aged 68 (maternal and paternal grandparents of Portuguese ancestry), was living at the time of examination in the city of Rio Grande. She showed the first symptoms of disease in June 1959, and blood was tested on 18 November 1965. At the time of examination the only symptom she presented was splenomegaly and clinically she was considered to be in good health. No information is available about previous treatment and transfusions. Haematological tests performed in 1965 showed 82,000 leucocytes $(0.5 \%$ leucoblasts $), 413 \mathrm{~m} / \mathrm{cmm}$ red blood cells, and a haemoglobin level of $80 \%$ of the normal. She was diagnosed as having chronic myeloid leukaemia. Blood group antigens did not show any abnormality but there appeared to be a depression in the $\alpha$ and $\beta$ agglutinins in the plasma (group $O$, titre of anti-A $1: 2$ against $1: 32$ in the control; anti-B: 1:1 against 1:32 in the control).

\section{Case 157075}

A white man, aged 57 (maternal grandparents of German ancestry, paternal grandparents of Spanish ancestry), was living at the time of investigation in the city of Pelotas. He showed the first symptoms of disease in May 1962, and blood was tested on 18 November 1965. At the time of examination he showed adenopathy, splenomegaly, and hepatomegaly; his clinical condition was considered to be fair. $\mathrm{He}$ had not been treated with corticoid and antimetabolite drugs since June 1965 and had received radiotherapy in 1963 but never any blood transfusion. Haematological tests performed in 1965 showed
41,000 leucocytes (44\% leucoblasts) and $214 \mathrm{mc} / \frac{\text { (s) }}{\Rightarrow}$ $\mathrm{mm}$ red blood cells. The diagnosis was of chronic. lymphoid leukaemia. He presented two abnor- $\overrightarrow{\vec{H}}$ malities in blood group antigens, a depression in $A_{1}$ (45\% of agglutination against $96 \%$ in the control) and a rise in an $\mathrm{H}$-like element $(14 \%$ of agglutination against $3 \%$ in the control) $\omega$ Evidence that he was genetically of group $\vec{A}_{\dot{\omega}}$ and not an intermediary was obtained through $\Theta$ the testing of his daughter, who had a normal ? group A blood; his wife was group $O$. No changes in his $\beta$ agglutinin were detected. The inhibition $\mathbb{D}$ titre of saliva was $\mathrm{A}$ antigen, $1: 8$, and $\mathrm{H}$ antigen, $1: 1$; that of his daughter was $A 1: 64$ and of $\mathrm{H}, \stackrel{\frac{\rho}{2}}{1: 16}$ $1: 16$.

The frequency of Australia antigen in the $\vec{\theta}$ leukaemia patients appears to be somewhat less. than that found in American populations, but since the numbers tested in Brazil are small these differences may not be significant.

As noted above, Australia antigen is not found in increased frequency in lepromatous leprosy in $\stackrel{\varnothing}{\varnothing}$ areas where the antigen is not common in the $\vec{F}$ general population. However, it is significantly more common in lepromatous leprosy in areas where its frequency is high in the general population. Thus the frequency of Australia antigen in lepromatous leprosy in the Philippines and? India is nearly twice as high as it is in the normal populations or in those patients with tuberculoid leprosy. From this we may surmise that lepromatous leprosy patients are more susceptible to chronic infection with hepatitis, but this would 은 not become manifest unless the organism were $D$ relatively common in the general population.

The antigen seems to be rare in healthy white $N$ and negro Brazilian populations (no reactors among 275 white and two among 358 negroid subjects; see Table I). This is a finding which is not much $\mathrm{\omega}$ at variance with previous results. Thus, Blumberg et al (1966) did not find the antigen among 6070 US Negroes or 101 Italians, and only one out of 44 Portuguese living in Hawaii showed it.

We wish to thank the Directors of the Instituto de Pesquisas Biologicas, the Health Centre in Flori- ¿ anópolis, and the Sanatorium Colônia Santa Tereza for allowing us to collect blood and other information at these institutions. Our colleagues, Girley V. Simões, Marlene Ferlauto, A. R. Schwantes, and M. Ayres, helped in the collection of the material and in many other ways. This work has been supported in part by 
the Rockefeller Foundation, Conselho Nacional de Pesquisas, Conselho de Pesquisas da Universidade Federal do Rio Grande do Sul, research grants GM-08238, CA-06551, CA-08069 and FR-05539, an appropriation from the Commonwealth of Pennsylvania, and a grant from the World Health Organization.

\section{References}

Ayres, M., Salzano, F. M., and Ludwig, O. K. (1966). J. med. Genet, 3, 180-185.

Bayer, M. E., Blumberg, B. S., and Werner, B. (1968). Nature (Lond.), 218, 1057-1059.

Blumberg, B. S. (1964). Bull, N.Y. Acad. Med., 40, 377-386.

Blumberg, B. S., Alter, H. J., and Visnich, S. (1965). J. Amer. med. Ass., 191, 541-546.

Blumberg, B. S., Friedlaender, J. S., and Woodside, A. (1969a). Proc. nat. Acad. Sci. (IVash.) In the press.

Blumberg, B. S., Gerstley, B. J. S., Hungerford, D. A., London, W. T., and Sutnick, A. I. (1967a), Ann. intern. Med., 66, 924-931.
Blumberg, B. S., Melartin, L., Guinto, R., and Lechat, (1969b). In preparation.

Blumberg, B. S., Melartin, L., Guinto, R., and Werner, (1966). Amer. J. hum. Genet., 18, 594-608.

Blumberg, B. S., Melartin, L., Lechat, M., and Guinto, (1967b). Lancet, 2, 173-176,

Blumberg, B. S., and Riddell, N. M. (1963). J. clin. Invest., 867-875.

Blumberg, B. S., Sutnick, A. I., and London, W. T. (1968). Bi N.Y. Acad. Med., 44, 1566-1586.

London, W. T., Sutnick, A. I., and Blumberg, B. S. (196\% Ann. intern. Med., 70, 55-59.

Melartin, L., and Blumberg, B. S. (1966). Nature (Lond.), $2 \overline{\overline{\text { A }}}$ 1340-1341.

Salzano, F. M., Rocha, F. J. da, and Tondo, C. V. (1968). $A \overbrace{\text { eqt }}$ genet. (Basel), 18, 449-457.

Salzano, F. M., Suñe, M. V., and Ferlauto, M. (1967). Ac çt genet. (Basel), 17, 530-544.

Schwantes, A. R., Salzano, F. M., Castro, I. V. de, and Tondo C. V. (1967). Acta Genet. (Basel). 17, 127-136.

Sutnick, A. I., London, W. T., Gerstley, B. J. S., Cronluise M. M., and Blumberg, B. S. (1968). J. Amer. med. As $205,670-674$ 